\title{
INTEGRATING FUZZY-SERVQUALINTO IMPORTANCE PERFORMANCE ANALYSIS AND QUALITY FUNCTION DEPLOYMENT FOR IMPROVE KSP KUSUMA ARTHA LESTARI SERVICE QUALITY
}

\author{
Ely Wijayanti, SundayNoya \\ Industrial EngineeringStudyProgramMaChungUniversity \\ e-mail: sunday.alexander@machung.ac.id
}

\begin{abstract}
KSP KusumaArtha Lestari $(K A L)$ is one of the credit unions in Malang and is engaged in providing financial services to its members. Over the last four years, the amount of loans KAL could distribute decreased. The decline may be caused due to the services quality provided by KAL does not meet consumer expectations. The measurement of service quality with FuzzyServqual questionnaire and gap analysis methods, it was found that there are ten KAL's service quality attributes that do not meet consumer expectations and need to be improved. Using Importance Performance Analysis, attributes that will be improved are determined, they are accessible location, availability of media published products KAL offered, the queue at the customer service, clear information employee can give to consumers, and the consumer complaints feedback quickness. By the Quality Function Deployment analysis, the improvement recommendations made. The recommendation are to add special customer service, to provide a suggestion box, to make documentation on consumer complaints, to maximize shuttle service, to open new branch office and improve its effectiveness, to add amount of media information, to add amount of information on every media, and to provides an indicator of the service quickness.
\end{abstract}

Keywords: Service Quality, Fuzzy-Servqual, QFD.

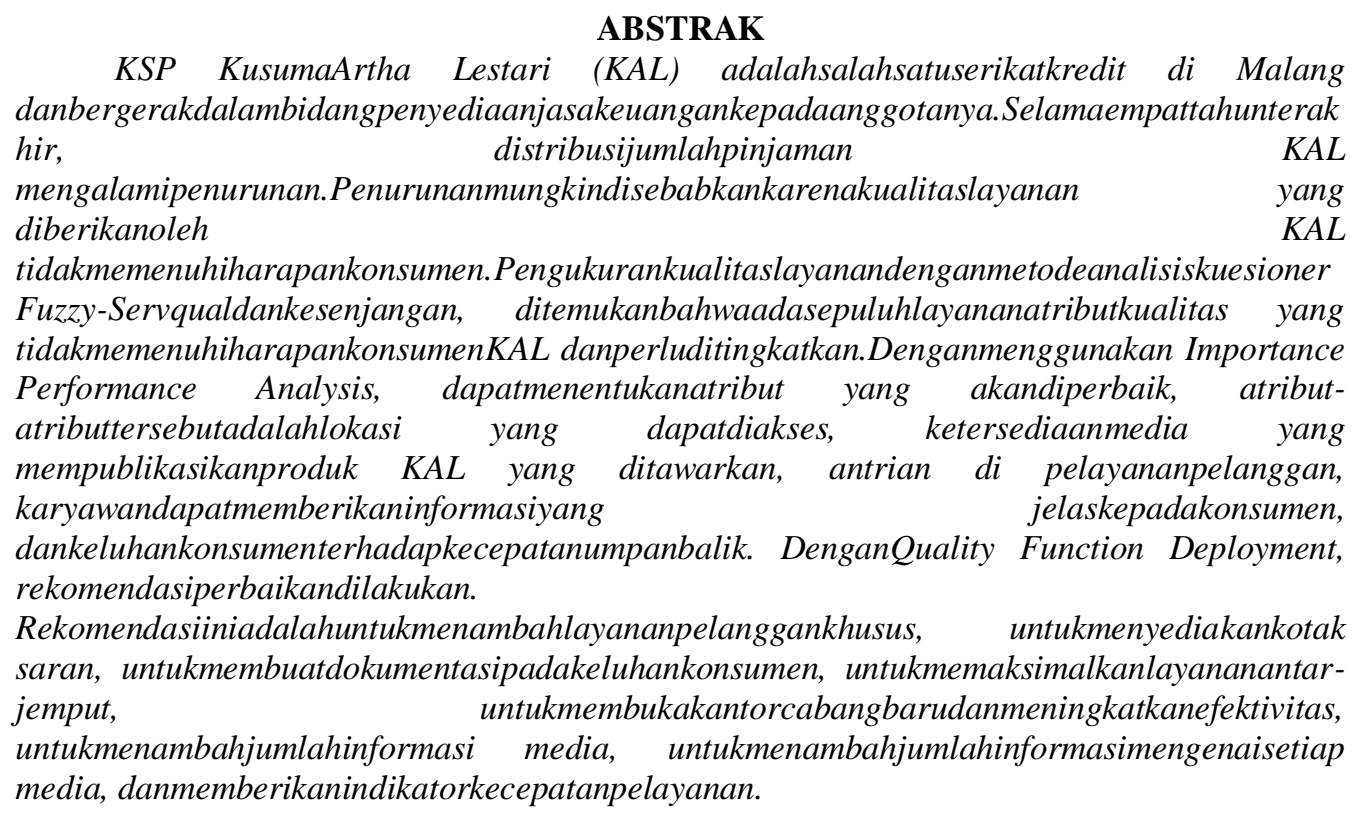

Kata kunci: KualitasPelayanan, Fuzzy-Servqual, QFD.

\section{INTRODUCTION}

Services industry has a significant role in the economy of countries around the world [1]. KusumaArtha Lestari (KAL) is one of the savings and credit cooperatives in Malang. This economic enterprise is widely known as a service cooperative because the cooperative is engaged in provide financial services to its members, such as savings, fixed deposits, and loans. 
During 2012, financial service growth is quite large, amount to 7.15\% [2]. In fact, over the past five years KAL did not experience significant growth. KAL productivity is measured by the amount of funds that can be lent to members each year. The amount of loans that was lent by KAL in the last 5 years shown in the Figure 1.

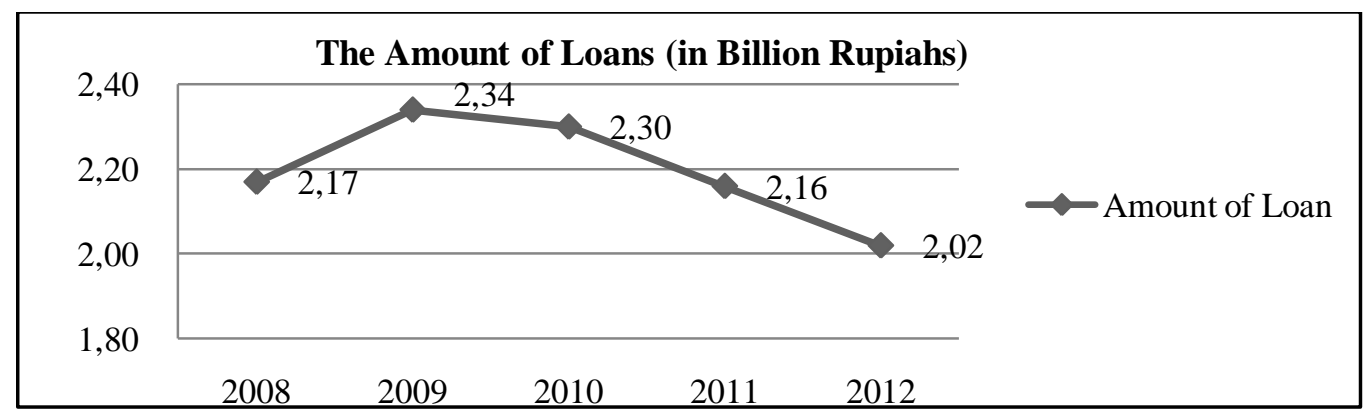

Figure 1. The Amount of Loans in 2008-2012

Decrease in the number of loans in the KAL can be caused by certain factors, both external and internal [3]. External factors that can cause a decrease in the amount of loans in KAL are change in economic, social, and cultural circumstances. Such changes can affect consumer behavior in the use of KAL financial services. In addition, the success of service industry like KAL will greatly depend on its service delivery process and service quality. Service delivery and service quality that not meet customer expectations can cause to customers dissatisfaction, and decrease amount of loan.

Based on a brief interview with five customers, obtained information that KAL still needs to improve its service in certain aspects, such as the speed in responding consumer problems.On the other hand, sometimes customers feel uncomfortable with the employees courtesy, which are considered excessive. This service quality, in the end can influence customer satisfaction and lead customers reluctant to consume financial services offered by KAL.

In resolving the issue related with service quality, this research is conducted to answer problem about the existing level of service quality in KAL, dimensions of service quality needs to be improved, and the application of Importance Performance Analysis (IPA) and Quality Function Deployment (QFD) in improving the service quality at KAL.

\section{LITERATURE REVIEW}

Servqualwas developed by A. Parasuraman,et al. [4]. These studies identified ten basic dimensions in the service quality assessment, namely access, communication, competence, courtesy, credibility, reliability, responsiveness, physical evidence, and the ability to understand customer. This study also identified that there are five gaps that may affect service quality, namely knowledge gap, standards gap, delivery gap, communications gap, and service gap.

Servqualmodel was redeveloped by Parasuraman, et al. [5]. Afterthe development, service quality dimensions that were previously divided into 10 factors are summarized into five factors, namely reliability, responsiveness, assurance, empathy, andtangible. And then, quality of service is defined as a global assessment involves a service. This definition is then made into the following equation: $\mathrm{Q}=\mathrm{P}-\mathrm{E}$. where $\mathrm{Q}$ is the perceived quality, $\mathrm{P}$ is the customer perception about service received, and $\mathrm{E}$ is the expectation of the customer about services. Then, the equations are applied in the measurement scale. That scale describes the five servqualdimensions of service quality in the 22 attributes. The measurement model has been implemented and tested on companies engaged in banking 
services, credit card services, repair services, and telephone services. After the testing, it was found that the scale of measurement that have been developed is valid and reliable.

N. Achmad [6], in his research using the five dimensions of servqualmeasurement, regression analysis, and Structural Equation Modeling in telecommunications services company. Results of this study indicate that the five dimensions of service quality directly contribute to consumer satisfaction and buying interest. During its development, Servqualmeasurement model widely used with other methods to analyze and improve the service quality in many kind of service industries. Research conducted by R. Fitriati [7] combines Methods Servqualand Importance-Performance Analysis (IPA) to examine the quality of public services TransJakarta. Analysis using IPA done to get service quality dimensions priority that need to be repaired. Whereas S. F. Siregar try combining the methods ofServqualmeasurement and Potential Gain Customer Value Index (IPGCV) to analyze service quality in Bank Muamalat Indonesia in Medan [8]. IPGCV can help to develop recommendations and priorities for service quality improvements to meet the consumer needs. D. J. Prawira, et al. using Quality Function Deployment (QFD) to improve the service quality at an airline flight [9]. After a SERVQUALmeasurement, improvement conducted by making a House of Quality (HOQ). HOQ is a technical graphics used in QFD to help develop solutions or improvements to meet customer needs.

In the previous studies, assessment of service quality with Servqualused Likert scale, but in the study conducted by E. Aryani used Servqualwhich integrated with Fuzzy method to analyze the quality of care in a hospital [10]. From Fuzzy-Servqual questionnaire, the data obtained in the form Fuzzy numbers, therefore need to dodefuzzification process in order to get crisp (real) numbers and can be processed for further analysis. Integration method and Fuzzy-Servqual is used to obtain results that are better able to accommodate the uncertainty and imprecision consumers' assessment of service quality is subjective.

\section{RESEARCH METHODOLOGY}

This study begins with the collection of data relating to the assessment of consumer expectations and perceptions about services. The assessment is obtained through a questionnaire based on the five dimensions of SERVQUALmodel and fuzzy number concept. The scales used in the questionnaire are on Table 1 [9], [11], [12].

Table 1.Questionnaire Scale

\begin{tabular}{ccc}
\hline Scale & Expectation or Importance & Perception \\
\hline 1 and 2 & Very Unimportant & Very Dissatisfied \\
2,3 , and 4 & Unimportant & Dissatisfied \\
4,5 , and 6 & Slightly Important & Slightly Satisfied \\
6,7 , and 8 & Important & Satisfied \\
8 and 9 & Very Important & Very Satisfied \\
\hline
\end{tabular}

The number of respondents to this questionnaire Slovin determined using the following formula [13]:

$n=\frac{N}{1+N \alpha^{2}}$

$\mathrm{n}:$ number of samples

$\mathrm{N}$ : number of population

$\alpha$ :accuracy rate

With number of population of 247 and a $10 \%$ accuracy rate, the minimum number of samples obtained was 71.18 or become 80 respondents. 
The data obtained were tested for its validity and reliability. Then, do the fuzzification and defuzzification to obtain crisp values of fuzzy values [9], [14]. Here is the formula that is used to perform the data fuzzification and defuzzification.

$$
\begin{aligned}
& \mathrm{a}_{\mathrm{i}}=\frac{\mathrm{b}_{1} \times \mathrm{n}_{1}+\mathrm{b}_{1} \times \mathrm{n}_{2}+\mathrm{b}_{2} \times \mathrm{n}_{3}+\ldots+\mathrm{b}_{(\mathrm{k}-1)} \times \mathrm{n}_{\mathrm{k}}}{\mathrm{n}_{1}+\mathrm{n}_{2}+\mathrm{n}_{3}+\cdots+\mathrm{n}_{\mathrm{k}}} \\
& \mathrm{b}_{\mathrm{i}}=\frac{\mathrm{b}_{1} \times \mathrm{n}_{1}+\mathrm{b}_{2} \times \mathrm{n}_{2}+\mathrm{b}_{3} \times \mathrm{n}_{3}+\ldots+\mathrm{b}_{\mathrm{k}} \times \mathrm{n}_{\mathrm{k}}}{\mathrm{n}_{1}+\mathrm{n}_{2}+\mathrm{n}_{3}+\cdots+\mathrm{n}_{\mathrm{k}}} \\
& \quad \mathrm{c}_{\mathrm{i}}=\frac{\mathrm{b}_{2} \times \mathrm{n}_{1}+\mathrm{b}_{3} \times \mathrm{n}_{2}+\mathrm{b}_{4} \times \mathrm{n}_{3}+\ldots+\mathrm{b}_{\mathrm{k}} \times \mathrm{n}_{(\mathrm{k}-1)}+\mathrm{b}_{\mathrm{k}} \times \mathrm{n}_{\mathrm{k}}}{\mathrm{n}_{1}+\mathrm{n}_{2}+\mathrm{n}_{3}+\cdots+\mathrm{n}_{\mathrm{k}}} \\
& \text { Defuzzifikasi }=\sqrt[3]{a_{i} \times b_{i} \times c_{i}}
\end{aligned}
$$

Research continued to count the gap 5 or the service gap with the formula (2-1) to determine customer satisfaction for each service quality attribute.

Questionnaire data that have been processed, then analyzed using the Importance Performance Analysis (IPA). IPA is used to plot attributes of service quality into four categories, namely concentrate here, keep up the good work, low priority, and possible overkill [15].

Next step is the formulation of improved service quality by using Quality Function Deployment (QFD). This method is implemented by making the House of Quality (HOQ) with following matrices [16]:

1. Consumer Need Matrix

This matrix contains the attributes of service quality in the KAL will be improved to meet customer expectations. Attributes of service quality will be improved are service quality attributes in quadrant A (Concentrate Here) from IPA analysis. This matrix consists of some columns, namely Voice of Customer (VoC), Importance to Customer (IoC), Relative Weight, and priority of VoC

2. Planning Matrix

Planning matrix consists of columns, namely Customer Satisfaction Performance (CuSP) and Competitive Customer Satisfaction Performance (CoSP). This matrix contains consumer ratings of service KAL and service competitors.

3. Technical Response Matrix

Technical response matrix contains the KAL managementresponse offered to improvedeach attribute of service quality in VoC.

4. Relationship Matrix between Consumer Needs and Technical Response

This matrix contains strong or weak ties between attributes of service quality in the VoC with technical responses provided by management.

5. Technical Correlation Matrix

This section is filled to see the relationship between two technical responses to customer needs KAL. Is technical response given mutually reinforcing, not affect, or the opposite.

6. Technical Matrix

Technically Matrix contains priority of technical response. Completion of this matrix also includes the existing specification, the target specification, Difficulties, weight importance which is the product of the values in the matrix of relationships and the value of IoC, and relative weight. 


\section{Result Data Processing Fuzzy-Servqual}

\section{RESULTS AND DISCUSSION}

Table 2.indicate value for the level of expectation and perception of each attribute that has didefuzzifikasi and also calculating the value gap 5.

\begin{tabular}{cccc}
\multicolumn{4}{c}{ Table 2.Level of Perception, Expectation, and Gap 5 } \\
\hline Attribute Code & $\begin{array}{c}\text { Perception } \\
(\mathbf{P})\end{array}$ & $\begin{array}{c}\text { Expectation } \\
(\mathbf{E})\end{array}$ & $\begin{array}{c}\text { Gap 5 } \\
(\mathbf{Q})\end{array}$ \\
\hline T1 & 4.68 & 7.21 & -2.53 \\
T2 & 4.56 & 6.31 & -1.75 \\
T3 & 6.99 & 6.54 & 0.45 \\
T4 & 6.46 & 6.11 & 0.35 \\
T5 & 6.62 & 5.98 & 0.64 \\
T6 & 5.88 & 7.19 & -1.31 \\
RL1 & 7.19 & 6.22 & 0.97 \\
RL2 & 4.18 & 6.81 & -2.63 \\
RL3 & 6.41 & 4.41 & 2.00 \\
RL4 & 6.57 & 6.14 & 0.42 \\
RL5 & 6.65 & 5.62 & 1.03 \\
RP1 & 5.48 & 5.88 & -0.40 \\
RP2 & 4.38 & 6.71 & -2.33 \\
RP3 & 7.06 & 6.75 & 0.31 \\
RP4 & 4.03 & 7.29 & -3.25 \\
A1 & 6.71 & 7.65 & -0.94 \\
A2 & 6.73 & 7.14 & -0.41 \\
A3 & 6.44 & 5.97 & 0.48 \\
A4 & 7.07 & 6.71 & 0.37 \\
E1 & 7.03 & 6.83 & 0.20 \\
E2 & 6.98 & 6.69 & 0.29 \\
E3 & 7.44 & 6.39 & 1.05 \\
E4 & 6.71 & 7.68 & -0.97 \\
\hline
\end{tabular}

With calculating value of gap 5 above, customer satisfaction with KAL service quality can be seen. Based on the gap 5 calculation, there are ten KAL service quality attributes that do not meet consumer expectations, its gap-5 value are negative.

\section{Result Data Processing Importance Performance Analysis (IPA)}

Importance Performance Analysis is performed to determine which attributes would be the priority of improvement in the KAL service quality. The service quality attributes can divided into four quadrants can be seen in Figure 2.

From the diagram can be seen that the KAL service quality attributes can be divided into four quadrants, namely:

1. Quadrant A(Concentrate Here), attributes in this quadrant considered important but the performance is not satisfactory. Therefore, these attribute need to be considered and prioritized for repair. KAL service quality attributes belonging to the quadrant A are:
a. T1
: Accessible location
b. T6
: Available media which haveproduct information 

c. RL2 : Short queue at customer service
d. RP2 : Employees provide clear information to consumers
e. RP4 : Institutions provide quick feedback to consumer complaints

2. Quadrant B, the attributes in this quadrant are considered important and satisfactory performance. Management just needs to make sure it remains stable performance attributes. KAL service quality attributes that includes in quadrant B are:
a. T3 : Good lighting room
b. RP3 : Satisfactory services provided
c. A1 : Transactions are secure
d. A2 : Parking area is secure
e. A4 : Employees are able to answer consumer questions
f. E1 : Services provided equally without regard to social status
g. E2 : Good communication between employees and customers
h. E3 : Employees are able to give a good impression
i. E4 : The employees are always ready to help consumers

3. Quadrant C, attributes in this quadrant are considered its performance isunsatisfactory. However, management does not need to prioritize the improvement of these attributes because the low level of importance. The service quality attributes that includes in quadrant $\mathrm{C}$ are:
a. T2 : Adequate parking area
b. RP1 : Employees are responsive in serving customers

4. Quadrant D, the attributes in this quadrant low interest rate but have high performance. Therefore, management should allocate resources in this attribute to other attributes that need improvement. Service quality attributes that includes in quadrant D are:
a. T4 : Room is always clean
b. T5 : Employees are always well-dressed
c. RL1 : Transaction processis easy
d. RL3 : Office operates according to the scheduled time
e. RL4 : Transaction receipt are always printed correctly
f. RL5 : Institution is reliable in dealing with consumer issues
g. A3 : The attitude of the employees were friendly to the consumer 


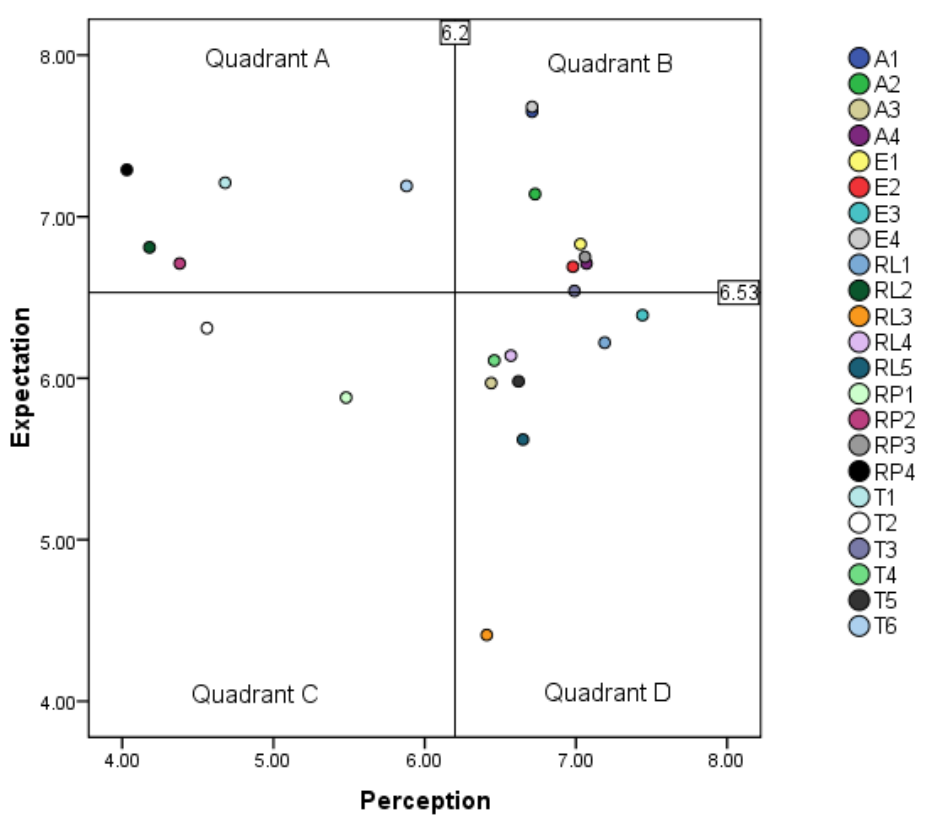

Figure2.IPA Diagram for KAL Service Quality

\section{Result Data Processing Quality Function Deployment (QFD)}

Next step for service quality analysis on KAL is Quality Function Deployment (QFD) analysis by composing the House of Quality (HOQ). The following are somerecommendations which arranged in accordance with the priority of improvements in HoQ.

1. The addition of customer service for consumer consultation or request information related to the KAL products.

Customer service is intended specifically to provide adequate information for consumers, consulting services and registration of members, as well as receive service complaints. With the separation of customer service task, consumers do not have to queue at the customer service. In addition, if the customer service task receivingservice complaint, KAL management can reach consumer complaintsfaster.

2. Provide suggestion box to accommodate consumer complaints

With the suggestion box, it is expected that consumers reluctant to make complaints in person can be free to submit their complaint in writing and complaints can be better documented.

3. Keep records for consumer complaints.

With the recording, consumer complaints will be documented properly and minimize management can missed to solve the complaints. Recording of consumer complaints can be discussed at the regular meetings held by KAL management. With the recording, any consumer complaint resolution developments can also be monitored.

4. Maximizing shuttle service.

KAL currently has a shuttle service to fund and important documents that missed when consumers come to the KAL office. However, not all members have known that KAL provide this service. Therefore, maximize and inform members about this service, satisfaction related attributes accessible location can be improved.

5. Adding and maximize the presence of branch offices.

KAL currently has a head office and a branch office in Malang. Management plans to open a branch office. In the opening of a new branch office planning, management also 
needs to consider the location choice. The selected location should be close to the main streets or close to most KAL members. Management also need to considered interoffice connectivity. So far, though KAL has two offices, two offices KAL services are not connected with each other. People who are members in the head office cannotdo transactions in the branch office. In order to achieve customer expectations related to the location, the KAL offices should be connected.

6. The addition of media containing product information KAL

KAL is currently only using banner and brochure as an information media. With the addition of the media used, consumers will have more choices to access information media. Management may choose to use media such as television that interesting for placement in the office. With the increasing use of the Internet, management can also use websites as a information media and reach consumers.

7. Addition information is available on any media.

KAL currently using brochure and banner to inform the products offered. Beside media addition, management can also perform additional information on every media. With the information addition on every media, will improve the efficiency of brochures and banners use.

8. The use of service quickness indicator on the customer service process.

The use of servicequickness indicators like an hourglass, consumer can help KAL management to control customer service performance. KAL customer service will also be more motivated to improve their service quickness.

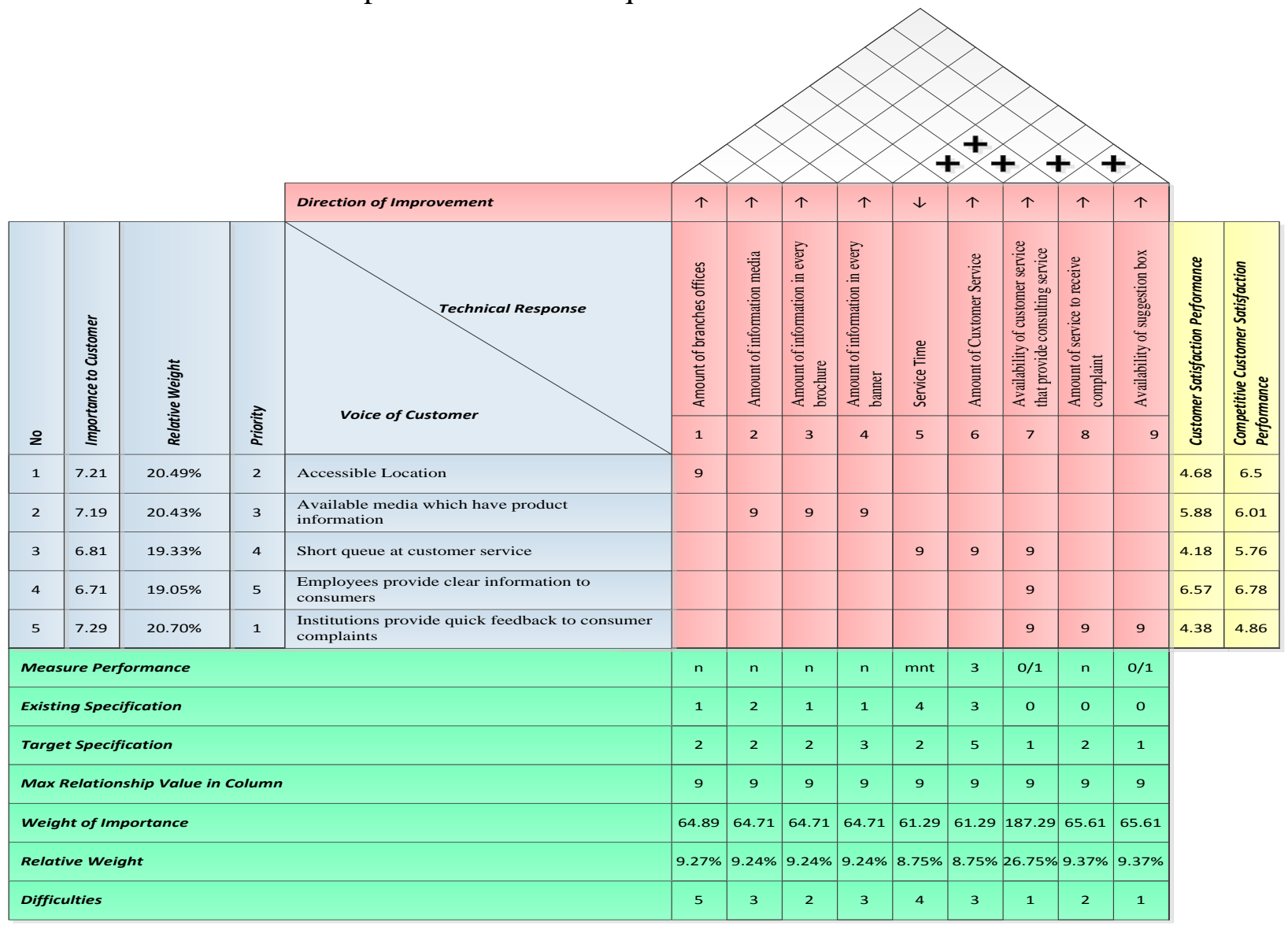

Figure 3. House of Quality 


\section{CONCLUSIONS}

Based on Fuzzy-Servqual analysis on KSP KusumaArta Lestari (KAL) service quality, it can be seen that there are ten service quality attributes that do not meet consumer expectations and has negative value in gap 5. These attributes are 3 attributes from tangible dimension, 1 attributes from reliability dimension, 3 attributes from responsibility dimension, 2 attributes from assurance dimension, and 1 attribute from empathy dimension.

The analysis using the Importance Performance Analysis found five attributes which belong to the quadrant $\mathrm{A}$ (Concentrate Here) and prioritize to improve. These attributes are accessible location, available media that contains product information, shorter queues at customer service, employee giving clear information to members, and cooperatives provide quickly feedback to complaints member.

Based on the Quality Function Deployment analysis, some recommendations that can be applied to improve KAL service quality, namely the addition of specialized customer service, provide suggestion box, records consumer complaints, maximize the shuttle service, add the amount and maximize the presence of branch office, add information media, add information on every information media, and use speed indicator on the customer service

\section{REFERRENCES}

[1]. F. Tjiptonodan G. Chandra, 2007, Service, Quality, \& Satisfaction, Edisi 2, PenerbitAndi Yogyakarta.

[2]. BadanPusatStatistik, 2013,PertumbuhanEkonomi Indonesia, BadanPusatStatistik, Jakarta.

[3]. L. Alfansi, 2010, Financial Service Marketing, PenerbitSalembaEmpat.

[4]. A. Parasuraman, V. A. Zeithaml, dan L. L. Berry, 1985, A Conceptual Model of Service Quality and Its Implications for Future Research, Journal of Marketing, 49(1):41-50.

[5]. A. Parasuraman, V. A. Zeithaml, dan L. L. Berry, 1988, SERVQUAL : A MultipleItem Scale for Measuring Consumer Perception of Service Quality, Journal of Retailing, 64 (1):12-40.

[6]. N.

Achmad, 2007 , AnalisisSimultanKualitasLayananTerhadapKepuasanKonsumendanMinatBelipadaGr apariTelkomsel di Surakarta, JurnalDayaSaing, 8(2) : 52-66.

[7]. R. Fitriati, 2010,

GagalkahTransJakarta? KajianKualitasLayananpadaSistemAngkutanCepatMassalTransJakarta, JurnalManajemenBisnis, 3(1):75-98.

[8]. S. F. Siregar, 2006, Analisis Tingkat KualitasPelayanandenganMetode Index Potential Gain Customer Value (PGCV) Di PT. Bank Muamalat Indonesia Cabang Medan, JurnalSistemTeknikIndustri, 7(4):40-47.

[9]. D. J Prawira, M. Iqbal, dan A. Kurniawati, 2012, UsulanPerbaikanKualitasLayananMaskapaiPenerbangan X MenggunakanIntegrasi QFD dan Model Kano, JurnalTeknikIndustri, 13(2):142-150.

[10]. Aryani, 2009, PeningkatanKualitasPelayananJasaKesehatan di InstalasiRawatInapdenganMetodeSERVQUAL- FUZZY (Studi di RumahSakitUmum Daerah Jombang), JurnalPenelitianIlmuTeknik, 9(1):58-69. 
[11]. S. P. Astuti, W. Wilasari, dan D. E. Utami, 2009, MeningkatkanKualitasPelayanan di Bank Syariah, PenelitiandenganFuzzy-ServqualdanDimensi Carter, JurnalManajemenBisnis, 2(1):47-58.

[12]. W. Y. Wu, S. W. Hsiao, dan H. P. Kuo, 2004, Fuzzy Set Theory Based Decision Model for Determining Market Position and Developing Strategy for Hospital Service Quality, Total Quality Management, 15(4):439-456.

[13]. N. Setiawan, 2007 , PenentuanUkuranSampelMemakaiRumusSlovindanTabelKrejcie-Morgan: TelaahKonsepdanAplikasinya, MakalahdisampaikanpadaDiskusillmiahJurusanSosialFakultasPeternakanUnpad, Bandung.

[14]. L. A. Rahmawati, 2012, IntegrasiMetode Fuzzy-Servqualdan QFD sebagaiUpayaPeningkatanKualitasPelayananterhadapNasabah (StudiKasus di Bank BTN KCP Karanganyar), TugasSarjana, TeknikIndustri, FakultasTeknik, UniversitasBrawijaya.

[15]. K. Kitcharoen, 2012, The Importance-Performance Analysis of Service Quality in Administrative Departments of Private Universities in Thailand, ABAC Journal, 24 (3):20-46.

[16]. D.W. Ariani, 2002, ManajemenKualitas :PendekatanSisiKualitatif, PenerbitGhalia Indonesia. 